\title{
THE INFLUENCE OF SELECTED IONIC LIQUIDS ON ACTIVITY OF CHITIN DEACETYLASE
}

\author{
Izabela Aspras, Małgorzata Kamińska, Kamil Karzyński, Mateusz Kawka, \\ Małgorzata M. Jaworska*
}

Warsaw University of Technology, Faculty of Chemical and Process Engineering, Waryńskiego 1, 00-645 Warsaw, Poland

\section{Dedicated to Prof. Ryszard Pohorecki on the occasion of his 80th birthday}

\begin{abstract}
Chitin deacetylase is the only known enzyme which is able to deacetylate N-acetyl-D-glucosamine units in chitin or chitosan chains. As chitin can hardly be dissolved in organic/inorganic solvents, new solvents are still searched. Ionic liquids are promising for that application and for homophase enzymatic deacetylation. The aim of the work was to investigate the influence of selected ionic liquids on activity of chitin deacetylase.

It has been shown that [Amim] ionic liquids increase the activity of chitin deacetylase. The highest activity was observed for [Amim][Cl]. Ionic liquids with shorter (ethyl (C2)) and longer side chain (buthyl (C4)) only insignificantly influenced the activity of the enzyme. All tested ionic liquids with $[\mathrm{Br}]$ anion increased the activity of chitin deacetylase while the [Emim] and [Bmim] cation in combination with $[\mathrm{Cl}]$ anion inhibited the activity of the enzyme.
\end{abstract}

Keywords: chitin deacetylase, enzyme activity, imidasolium ionic liquids, pyridinium ionic liquids

\section{INTRODUCTION}

Chitin deacetylase $(\mathrm{ChD})$ is the only known enzyme which is able to deacetylate N-acetyl-Dglucosamine units (GlcNAc) in chitin or chitosan chains. In this process the acetyl group linked to amine grup in GlcNAc units is liberated and glucosamine units (GlcN) are formed (Jaworska 2012). As chitin is completely insoluble in most organic and inorganic solvents enzymatic deacetylation can be carried out only as heterophase process. Hence only those GlcNAc units that are exposed on the outer surface of chitin particles can be deacetylated. The majority of GlcNAc units are hidden inside the crystalline structure of chitin particle and enzyme has no access to them. Such process cause only slight change in acetylation degree (a percentage of GlcNAc units in polymer chain, AD) so changes in chitin properties are insignificant.

As chitin crystallinity and structure can be hardly modified by treating with organic/inorganic solvents, new methods for chitin modifications are still searched. Large group of solvents called ionic liquids (ILs) are promising for that application. It has been found that chitin can be dissolved in some ILs (Jaworska et al. 2012). The imidasolium ionic liquids are the most often reported as solvents for chitin. Among them the $[\mathrm{Amim}],[\mathrm{Bmim}]$ and $[\mathrm{Emim}]$ cations gave the best results. Using these ILs enzymatic deacetylation could be processed as homophase one. For homophase enzymatic deacetylation selected ionic liquids have to be able to dissolve chitin as well as should be enzyme friendly. Ionic liquids used for dissolution of chitin cannot act as inhibitors for chitin deacetylase. 
The interaction of ionic liquids and enzymes are not well understood so far. It depends on several factors (Gorke et al, 2010; $\mathrm{Mu}$ et al, 2012) as the anion and cation of ionic liquid, its polarity, hydrophobicity/ hydrofilicity, viscosity, length of a chain substituting a central ring. It has been reported that ILs can increase or decrease the activity of enzyme as well as can be neutral. The number of enzymes used in tests with ionic liquids is limited and it must be emphasised that there are no information of influence of ionic liquids on chitin deacetylase, so the presented paper is the first dealing with this subject.

The aim of present work was to investigate the influence of selected ionic liquids on chitin deacetylase activity. In our work the influence of cation ([Amim], [Emim], [Epyr], [Bmim]) and anion ([Cl], $[\mathrm{Br}]$, $[\mathrm{I}]$, [BSFI], [DCA]) was tested. Most tested Ils are hydrophilic, with exception of [Amim][BSFI] which is hydrophobic. They differ in the length of a chain substituting the imidasolium ring: C2 - [Emim], $\mathrm{C} 3-[\mathrm{Amim}], \mathrm{C} 4-[\mathrm{Bmim}]$ as well as a type of ring in a cation: imidasolium and pyridinium. Additionally [Amim] cation contains a double band in side chain. Such combination of anions and cations allows to investigate influence of ions on activity of chitin deacetylase.

In our investigations chitosan solution was used as a substrate, because chitosan is much easier deacetytlated enzymaticly than chitin, thus the effect of Il on activity of the enzyme will be much easier observed.

\section{MATERIALS AND METHODS}

\subsection{Chemicals}

The chitosan used in all experiments was kindly donated by BioLog Heppe (Germany). It was of medium molecular weight (viscosity of $1 \%$ solution in $1 \%$ acetic acid solution at $25^{\circ} \mathrm{C} \mu=200 \mathrm{~Pa} \cdot \mathrm{s}$, according to the producer data), and $\mathrm{AD}=22.8 \%$ (determined from the IR spectrum using the procedure of Domszy and Roberts (1985)). Chitosan (4g) was mixed with $500 \mathrm{~mL}$ of $\mathrm{HCl}$ solution ( $\mathrm{pH} 4.0$ ). Next $0.1 \mathrm{M} \mathrm{HCl}$ was added in small portions $(1-2 \mathrm{~mL}$ ) to complete polymer dissolution (the $\mathrm{pH}$ was controlled during dissolution and kept constant at $\mathrm{pH} 4.0 \pm 0.1)$ and it was adjusted to a final volume of $1.0 \mathrm{~L}$ with a $\mathrm{HCl}$ solution $(\mathrm{pH} 4.0)$.

Ionic liquids: 1-allil-3-methylimidasolium chloride ([Amim][Cl]), 1-allil-3-methylimidasolium bromide ([Amim][Br]), 1-allil-3-methylimidasolium bis(trifluoromethyl sulfonyl) imid ([Amim][BSFI]), 1-allil3-methylimidasolium dicianamide ([Amim][DCA]), 1-ethyl-3-methylimidasolium chloride ([Emim] $[\mathrm{Cl}])$, 1-buthyl, 3-methylimidasolium chloride ([Bmim] [Cl]), 1-buthyl, 3-methylimidasolium bromide ([Bmim] $[\mathrm{Br}])$, 1-buthyl, 3-methyl-imidasolium tosylate ([Bmim][TSO]) were kindly donated by Merck KgaA. Ionic liquids: 1-ethyl, 3-methylimidasolium bromide ([Emim][Br]), 1-ethyl-3methylimidasolium iodine ([Emim][I]), 1-ethylpyridinium bromide ([Epyr][Br]), 1-ethylpyridinium iodine ([Epyr][I]) were purchase in IoliTec (Germany).

All chemicals used in experiments were of analytical grade.

\subsection{Chitin deacetylase}

The enzyme separated from Absidia orchidis NCAIM F 00642 was used in all experiments (enzyme is not commercially available). The fungi were cultivated in a $7.0-\mathrm{L}$ batch culture $\left(26^{\circ} \mathrm{C}, \mathrm{pH} 5.5\right.$, YPG nutrient medium, Jaworska and Konieczna (2001)) and separated from the nutrient medium by centrifugation $\left(6000 \mathrm{rpm}, 20 \mathrm{~min}, 4^{\circ} \mathrm{C}\right)$. Next the biomass was frozen and then slowly thawed and homogenised, and the crude cell extract was separated (centrifugation, $6000 \mathrm{rpm}, 20 \mathrm{~min}, 4^{\circ} \mathrm{C}$ ) and 
salted out with ammonium sulphate $\left(80 \%\right.$ saturation) overnight at $4-6^{\circ} \mathrm{C}$. The solution was diafiltered with $\mathrm{HCl}(\mathrm{pH} 4.0)$ to remove ammonium sulphate (using a membrane module with a cut-off $10 \mathrm{kDa}$ ) and then concentrated by ultrafiltration (the same membrane module). This enzyme solution, adjusted to $\mathrm{pH} 4.0$ (optimal $\mathrm{pH}$ ) with $\mathrm{HCl}$, was used in all experiments. The activity of the preparation was in a range of 4.3-10.5 U/mL depended on experiment (where $1 \mathrm{U}$ is such amount of the preparation solution that form $1 \mu \mathrm{mol}$ of acetic acid during $10 \mathrm{~min}$ of reaction with chitosan ( $\mathrm{AD}=22,8 \%)$ as a substrate, at $\left.45^{\circ} \mathrm{C}, \mathrm{pH} 4.0\right)$.

\subsection{Activity of chitin deacetylase}

Experiments were carried out in a $100 \mathrm{~mL}$ thermostated, mixed $(200 \mathrm{rpm})$ reactor. Reactor was filled with $50 \mathrm{~mL}$ of chitosan solution and $50 \mathrm{mg}$ of ionic liquid was added. The solution was thermostated to reach the temperature of $45^{\circ} \mathrm{C}$ (approx. $10 \mathrm{~min}$ ) and the reaction was started by adding $1.0 \mathrm{~mL}$ of the chitin deacetylase solution. The activity of chitin deacetylase was measured using the method of initial rate. Reaction mixture was sampled $(2 \mathrm{~mL})$ in proper time intervals and the reaction was stopped immediately by adding $0.10 \mathrm{~mL} 1.0 \mathrm{M} \mathrm{NaOH}$. Chitosan was separated by centrifugation and the released acetic acid concentration in the clear supernatant solution was measured.

\subsection{Analytical methods}

Acetic acid concentration in the clear solution was analyzed using the HPLC method: isocratic system (Varian ProStar 210) with HyperREZ XP Organic acid column $\left(60^{\circ} \mathrm{C}\right)$ and HyperREZ XO Carbohydrate $\mathrm{H}^{+}$Guard Column, $0,0025 \mathrm{M} \mathrm{H}_{2} \mathrm{SO}_{4}$ as eluent $(0.5 \mathrm{~mL} / \mathrm{min})$, and refractometer detector (Varian ProStar 350). The quantification limit was evaluated at $5 \mathrm{nmol} / \mathrm{mL}$ with a standard deviation of $8 \%$ of the mean value. The method was validated for acetic acid determination in chitosan- $\mathrm{HCl}(\mathrm{pH}$ 4.0) solutions.

\section{RESULTS}

Twelve ionic liquids were tested to evaluate their influence on activity of chitin deacetylase. The ILs differed in cation and anion, so the interaction of an ion with the enzyme could be investigated. Most tested Ils were hydrophilic, while [Amim][BSFI] was hydrophobic. Because of different initial activity of the enzyme preparations used in experiments, results are presented as a percent of change in activity of the enzyme in comparison to experiment without ionic liquid. The results are presented in Figs. 1 to 3 .

The activity of chitin deacetylase strongly depended on ionic liquid used. The ethyl (C2) substitution of a cation ring is the shortest one among tested ILs. It was noticed that all ionic liquids with ethyl substitution had no influence on chitin deacetylase with exception of [Emim][Cl] when enzyme deactivation was observed, Fig. 1. ILs in this group differed in a type of a cation ring, but no significant differences between imidasolium and pyridinium ring on activity of chitin deacetylase was observed. Results for [Emim] $[\mathrm{Br}]$ and [Epyr] $[\mathrm{Br}]$ or for [Emim][I] and [Epyr][I] showed only small deviation from activity of native enzyme, so we can assume that these ionic liquids don't influence its activity. 


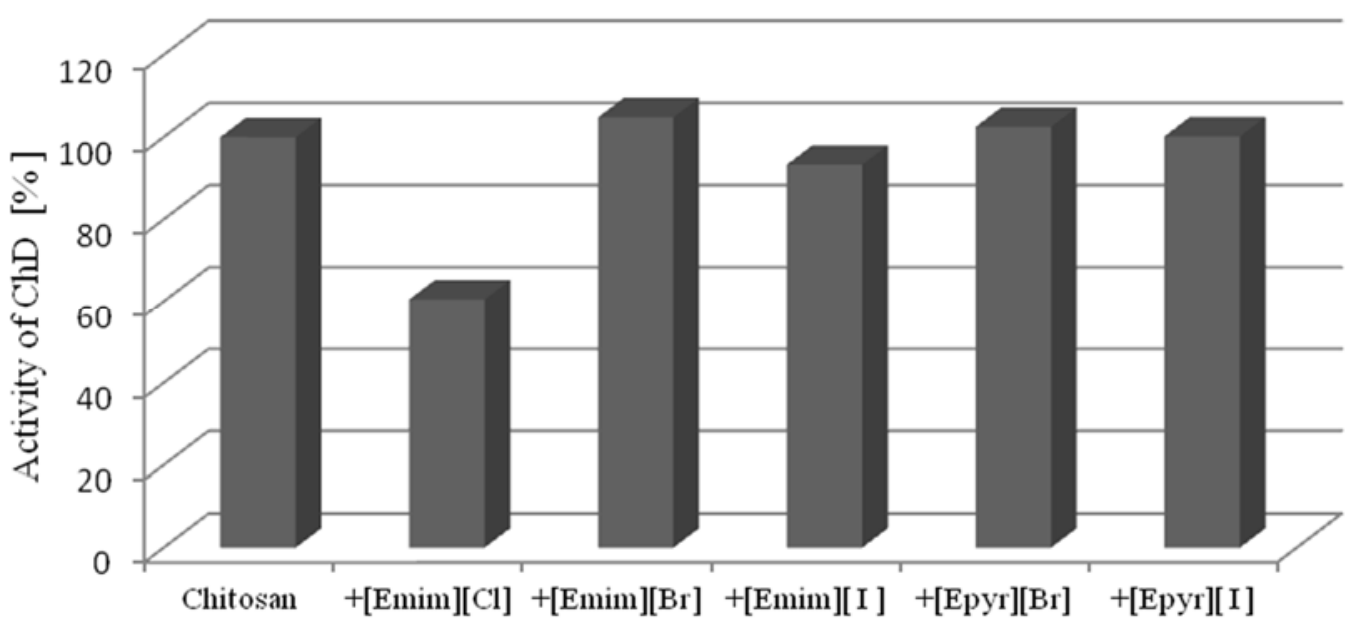

Fig. 1. The influence of [Emim] and [Epyr] ionic liquids on activity of chitin deacetylase

For [Amim] cation (C3) all tested ILs increased the activity of the enzyme without looking at the anion, Fig. 2. The highest increase in activity was noticed for $[\mathrm{Amim}][\mathrm{Cl}](139 \%)$ and it was the highest increase in activity for all tested ionic liquids. It was interesting that none of the ionic liquid tested here acted as inhibitor for chitin deacetylase, no deactivation was observed. The influence of hydrophobicity/ hydrophilicity seems as secondary factor, as data for hydrophobic ionic liquid ([Amim][BSFI]) did not deviate from data for the rest [Amim] ionic liquids, although the increase in activity of chitin deacetylase was the lowest.

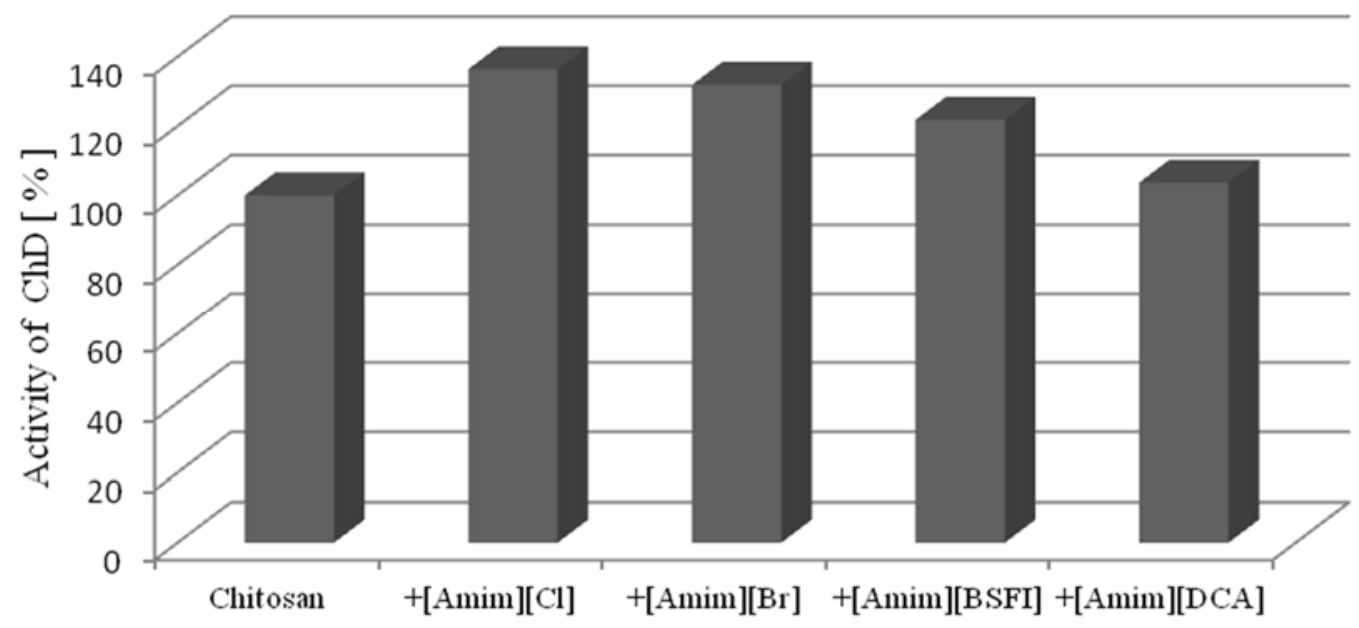

Fig. 2. The influence of [Amim] ionic liquids on activity of chitin deacetylase

The interaction between chitin deacetylase and ionic liquids with [Bmim] cation (C4) depended strongly on complementary anion, Fig. 3. For [Bmim] $[\mathrm{Br}]$ and $[\mathrm{Bmim}][\mathrm{TSO}]$ increase in activity $(115 \%$ and $110 \%$ respectively) was observed while for $[\mathrm{Bmim}][\mathrm{Cl}]$ the decrease was noticed.

Comparing the activity of chitin deacetylase with ionic liquids containing $[\mathrm{Cl}]$ anion the decrease in activity of the enzyme for [Emim] and [Bmim] cation was noticed while significant increase was measured for $[\mathrm{Amim}]$ cation. Contrary to that data, all tested ionic liquids with $[\mathrm{Br}]$ anion increased the activity of the enzyme. The increase in activity depended on cation and the highest value was observed for $[\mathrm{Amim}][\mathrm{Br}](131 \%)$ while the lowest value was noticed for $[\mathrm{Emim}][\mathrm{Br}](105 \%)$. 


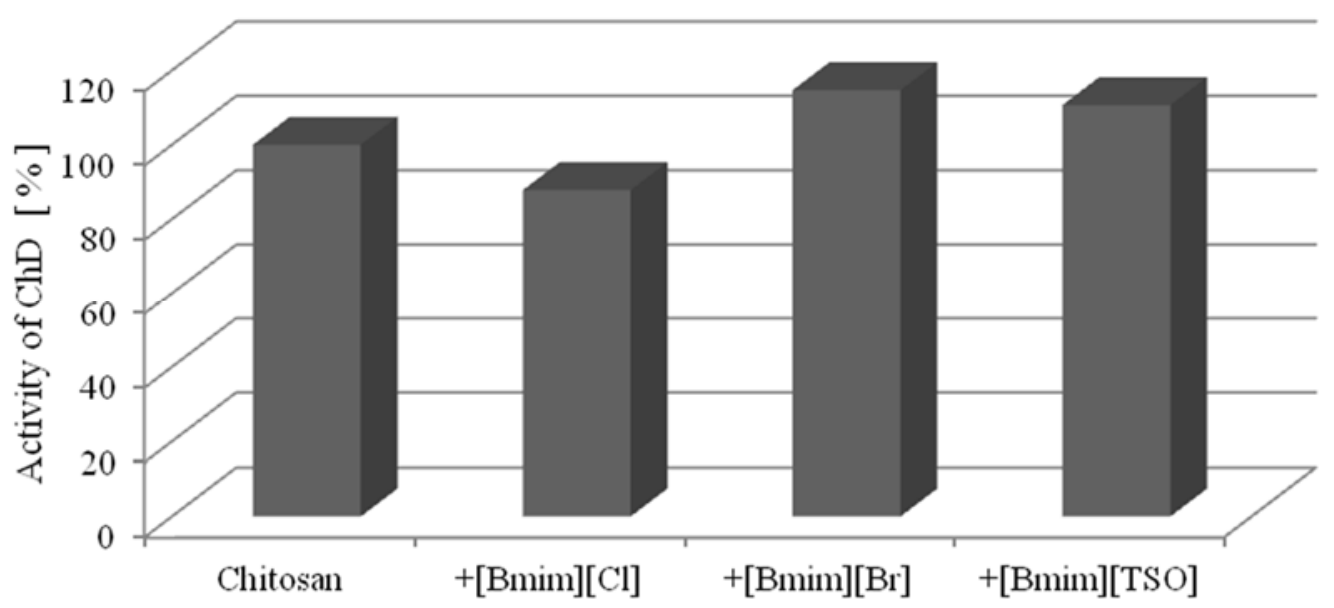

Fig. 3. The influence of [Bmim] ionic liquids on activity of chitin deacetylase

\section{CONCLUSIONS}

The interaction between ionic liquids and enzymes is complicated and not well understood. Several properties of ILs influence activity of enzymes and the effect of activation/ deactivation need to be evaluated individually for each enzyme. Ionic liquids were tested as good solvents for chitin and chitosan, but its interaction with chitin deacetylase has never been investigated. The present paper reveals such interaction for the first time.

In our investigations we have shown that [Amim] ionic liquids increase the activity of chitin deacetylase. The highest activity was observed for [Amim] $[\mathrm{Cl}]$. We have shown that hydrophobicity of tested Il ([Amim] [BSFI]) did not play important role as data were similar to that for the native enzyme. The presented data suggest that the short side chain (C3) with a double bond in allyl substitution of imidasolium ring promote activity of chitin deacetylase, although the double bond would suggest the opposite effect. Ionic liquids with shorter (ethyl (C2)) and longer side chain (buthyl (C4)) only insignificantly influenced the activity of $\mathrm{ChD}$. For these Ils the influence of complementary anions played important role. All tested ionic liquids with $[\mathrm{Br}]$ anion increased the activity of chitin deacetylase while only for [Amim] [Cl] such increase was observed. The [Emim] and [Bmim] cation in combination with $[\mathrm{Cl}]$ anion inhibited the activity of the enzyme. It was also interesting to notice that ionic liquids with pyridinium ring did not influence the activity of chitin deacetylase.

The tested ionic liquids differed also in viscosity, but $50 \mathrm{mg}$ of ionic liquid added to $50 \mathrm{~mL}$ of chitosan solution was not able to change the viscosity of reaction mixture in a degree that would influence the activity of chitin deacetylase. Such small amount of Il added will not also influence the polarity of the mixture, so the observed effects were the results of enzyme - ionic liquid interaction where the composition (cation and anion) of Il is important.

The mechanism of activation / deactivation of chitin deacetylase by ionic liquids will be investigated in our further works.

This work has been supported by the budget sources for The National Centre for Science (Poland), Grant no. DEC-2013/09/B/ST8/00144.

Authors would like to thank Merck KGaA for their kind donation of ionic liquids used in presented investigations. 


\section{SYMBOLS}

$\mathrm{AD}$ acetylation degree, $\%$

[Amim][Br] 1-allil-3-methylimidasolium bromide

[Amim][BSFI] 1-allil-3-methylimidasolium bis(trifluoromethyl sulfonyl) imid

[Amim][Cl] 1-allil-3-methylimidasolium chloride

[Amim][DCA] 1-allil-3-methylimidasolium dicianamide

[Bmim $][\mathrm{Cl}]$ 1-buthyl, 3-methylimidasolium chloride

[Bmim][Br] 1-buthyl, 3-methylimidasolium bromide

[Bmim][TSO] 1-buthyl, 3-methylimidasolium tosylate

$\mathrm{ChD} \quad$ chitin deacetylase

[Emim][Br] 1-ethyl-3-methylimidasolium bromide

[Emim][Cl] 1-ethyl-3-methylimidasolium chloride

[Emim][I] 1-ethyl-3-methylimidasolium iodine

[Epyr][Br] 1-ethylpyridinium bromide

[Epyr][I] 1-ethylpyridinium iodine

GlcN D-glucosamine unit

GlcNAc N-acetyl,D-glucosamine unit

ILs ionic liquids

\section{REFERENCES}

Domszy J.G., Roberts G.A.F., 1985. Evaluation of infrared spectroscopic techniques for analyzing chitosan. Makromol. Chem., 186, 1671-1673. DOI: 10.1002/macp.1985.021860815.

Gorke J., Srienc F., Kazlauskas R., 2010. Toward advanced ionic liquids. Polar, enzyme-friendly solvents for biocatalysis. Biotech. Bioproc. Eng., 15, 40-53. DOI: 10.1007/s12257-009-3079-z.

Jaworska M.M., Konieczna E., 2001. The influence of supplemental components in nutrient medium on chitosan formation by the fungus Absidia orchidis. Appl. Microbiol. Biotechnol., 56, 220-224. DOI: $10.1007 / \mathrm{s} 002530000591$.

Jaworska M.M., 2012. Kinetics of enzymatic deacetylation of chitosan. Cellulose, 19, 363-369. DOI: 10.1007/s10570-012-9650-3.

Jaworska M.M., Koźlecki T., Górak A., 2012. Review of the application of ionic liquids as solvents for chitin. J. Polym. Eng., 32, 67-69. DOI: 10.1515/polyeng-2011-0145.

Naushada M., Al Othman Z.A., Khan A.B., Maroof A., 2012. Effect of ionic liquid on activity, stability, and structure of enzymes: A review. Int. J Biol. Macromol., 51, 555-560. DOI: 10.1016/j.ijbiomac.2012.06.020. 